\title{
Concentrations of Butyric Acid Bacteria Spores in Silage and Relationships with Aerobic Deterioration
}

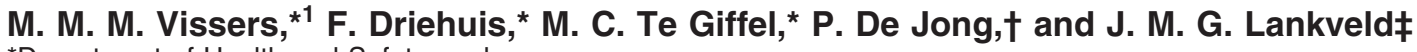 \\ *Department of Health and Safety, and \\ †Department of Processing, NIZO Food Research, PO Box 20, 6710 BA Ede, the Netherlands \\ fDairy Science, Wageningen University and Research Centre, PO Box 8129, 6700 EV Wageningen, the Netherlands
}

\section{ABSTRACT}

Germination and growth of spores of butyric acid bacteria (BAB) may cause severe defects in semihard cheeses. Silage is the main source of $B A B$ spores in cheese milk. The objectives of the study were to determine the significance of grass silages and corn silages as sources of $\mathrm{BAB}$ spores and to investigate the relationships between high concentrations of $\mathrm{BAB}$ spores in corn silage and aerobic deterioration. In the first survey, samples were taken from various locations in silos containing grass and corn silages and from mixed silages in the ration offered to the cows on 21 farms. We demonstrated that the quantity of $\mathrm{BAB}$ spores consumed by cows was determined by a small fraction of silage with a high concentration of spores (above $5 \log _{10}$ $\mathrm{BAB} / \mathrm{g})$. High concentrations were most often found in corn silage within areas with visible molds (69\% of the samples). Areas with visible molds in grass silage and surface layers of corn silage contained, respectively, 21 and $19 \%$ of the cases of concentrations above $5 \log _{10}$ $\mathrm{BAB}$ spores/g. Based on these results, we concluded that currently in the Netherlands, corn silage is a more important source of $\mathrm{BAB}$ than is grass silage. In a second survey, 8 corn silages were divided into 16 sections and each section was studied in detail. High concentrations of BAB spores were found in only the top $50 \mathrm{~cm}$ of these 8 silages. Elevated concentrations of BAB spores were associated with different signs of aerobic deterioration. In $13 \%$ of the sections in corn silage with more than $5 \log _{10}$ yeasts and molds/g, more than $5 \log _{10}$ BAB spores/g were found. Sections with a temperature of more than $5^{\circ} \mathrm{C}$ above ambient temperature contained, in $21 \%$ of the cases, more than $5 \log _{10} \mathrm{BAB}$ spores/g. Concentrations above $5 \log _{10} \mathrm{BAB}$ spores/g were measured in $50 \%$ of the sections with a pH above 4.4. All sections with a $\mathrm{pH}$ above 4.4 also showed a temperature that was more than $5^{\circ} \mathrm{C}$ above ambient temperature and a concentration of yeasts and molds above $5 \log _{10}$

Received June 7, 2006.

Accepted September 21, 2006.

${ }^{1}$ Corresponding author: marc.vissers@nizo.nl $\mathrm{cfu} / \mathrm{g}$. Based on these results, we postulated that high concentrations of BAB spores in corn silage are the result of oxygen penetration into the silage, resulting in aerobic deterioration and the formation of anaerobic niches with an increased $\mathrm{pH}$ just below the surface. Growth of BAB in these anaerobic niches with an increased $\mathrm{pH}$ caused the locally high concentrations of $\mathrm{BAB}$ in corn silage.

Key words: butyric acid bacteria, late-blowing, silage, aerobic deterioration

\section{INTRODUCTION}

In semihard cheeses, such as Gouda and Emmental, the growth of spore-forming bacteria of the genus Clostridium can lead to off-flavors and excessive gas formation. This defect is called late blowing. These bacteria, called butyric acid bacteria (BAB), are able to convert lactic acid into butyric acid, hydrogen, and carbon dioxide at relatively low $\mathrm{pH}$. In particular, Clostridium tyrobutyricum is associated with this problem (Klijn et al., 1995). Without preventive measures, late blowing of Gouda-type cheeses can occur at concentrations above $10 \mathrm{BAB}$ spores/L of pasteurized cheese milk (Stadhouders, 1990).

Spores of BAB in milk originate from the farm environment. Reducing the concentration of $\mathrm{BAB}$ spores in farm tank milk (FTM) is an important option to prevent late-blowing of cheeses (Stadhouders and Spoelstra, 1990). Additional measures are the removal of spores from milk by bactofugation, the addition of inhibitors, such as nitrate and lysozyme, and the use of nisinproducing cheese starter cultures (Stadhouders, 1990; Waes et al., 1990; Delves-Broughton et al., 1996). To encourage farmers to produce milk with low concentrations of BAB spores, Dutch dairies have FTM analyzed monthly for BAB spores. The milk payment by the dairies to farmers is partly dependent on the result of these tests. The objective of dairy processors is to have fewer than 1,000 BAB spores/L of FTM.

Silage is the most important source of $\mathrm{BAB}$ spores. The spores survive the passage through the alimentary tract of the cow and are excreted with the feces. Trans- 
mission to milk occurs via fecal contamination of the cow's teats (Bergere et al., 1968). Control of the concentration of $\mathrm{BAB}$ spores in silage is essential to control the concentration in FTM (Vissers et al., 2006). The preservation of forage by ensiling is achieved via the attainment of a low $\mathrm{pH}$ by lactic acid fermentation and the maintenance of anaerobic conditions within the silo. A rapid and sufficient decline in $\mathrm{pH}$ after ensiling decreases the chance of clostridial growth in silage. The rate and extent of $\mathrm{pH}$ decline are influenced by many factors, such as DM content, concentration of fermentable sugars and buffer capacity of the crop, and activity of the lactic acid bacteria flora (Weissbach, 1996).

The creation and maintenance of anaerobic conditions in silage is important to prevent the growth of aerobic microorganisms. However, in practice, exposure of silage to air is unavoidable. During storage, small amounts of air will penetrate the silage, for instance, because silage covers (usually plastic sheets) are not completely airtight. Calculations showed that during storage, oxygen can penetrate up to a depth of $0.2 \mathrm{~m}$ from the top of the silage (McGechan and Williams, 1994). After opening for feeding, air will usually penetrate via the silage face. Parsons (1991) calculated that after opening, oxygen can penetrate silage via the feedout face up to distances of $4 \mathrm{~m}$ from the feed-out face. During storage and after opening of the silage, surface layers are the most sensitive to the penetration of air. The main factors influencing the extent of air penetration are the porosity and density of the silage and the rate of silage feeding (Honig, 1991). As a result of air infiltration, acid-tolerant (facultative) aerobic microorganisms start to proliferate. This aerobic deterioration process is usually initiated by yeasts, which use residual sugars and lactic acid as substrates. As this process proceeds, the silage $\mathrm{pH}$ rises and other less acid-tolerant microorganisms, such as molds and Bacillus species, start to proliferate (Pahlow et al., 2003).

Traditionally, high concentrations of BAB spores in FTM were associated with anaerobically unstable silages made of crops with high buffer capacity, such as grass and alfalfa (Stadhouders and Spoelstra, 1990; Weissbach, 1996). Anaerobically unstable silages are generally characterized by a high $\mathrm{pH}$ and high levels of butyric acid and ammonia. Corn silages are considered a less significant source of BAB spores. Because of a combination of DM, fermentable sugars, and buffer capacity, silages made of corn generally have a fast $\mathrm{pH}$ decline and a low final $\mathrm{pH}(<4.0)$. These conditions do not allow significant growth of clostridia (Stadhouders and Spoelstra, 1990). Furthermore, Stadhouders and Spoelstra (1990) found low concentrations of BAB spores in unopened corn silage silos. However, Driehuis and Te Giffel (2005) recently identified corn silage as the main source of BAB spores on 5 dairy farms that produced FTM with an elevated level of BAB spores. A relationship was suggested between the occurrence of high concentrations of $\mathrm{BAB}$ spores in the corn silages and aerobic deterioration because concentrations of BAB spores above $5 \log _{10}$ most probable number (MPN)/ $\mathrm{g}$ were detected in surface layers. The objectives of this study were to determine the importance of grass silages and corn silages as a source of BAB spores in the ration of dairy cows on farms in the Netherlands (survey 1) and to further investigate the relationships between high concentrations of $\mathrm{BAB}$ spores in corn silage and aerobic deterioration (survey 2).

\section{MATERIALS AND METHODS}

\section{BAB Spores in Grass and Corn Silage (Survey 1)}

In the first survey, we visited 21 farms located in different regions in the Netherlands. Farms were selected based on the detection of BAB spores in FTM delivered to the dairy in 2004 using data from the Netherlands Milk Control Station (MCS, Zutphen, the Netherlands). Farms performing badly, moderately well, and well were selected to ensure that not only high-quality silages were surveyed. On these farms, all silages were ensiled in bunker or clamp silos and were covered with plastic sheeting. The width of the silages sampled ranged from 6 to $15 \mathrm{~m}$; the height ranged from 1.5 to $4 \mathrm{~m}$. On 3 farms, inoculants of an unknown brand were added to the grass and corn silages during ensiling. On each farm, samples were taken from the grass silage, from the corn silage, and from the mixture of these silages that was offered to cows in the barn. Per grass and corn silage, 3 samples were taken: a sample from the core, from the surface layer (outermost $0.2 \mathrm{~m}$ of the silage; Figure 1A) and from areas with visible molds. From both the surface layer and the core, 10 subsamples were taken at different positions and mixed to provide composite samples. Areas with visible molds (molded spots) and the $15 \mathrm{~cm}$ surrounding these areas were excluded from the core and surface layer samples. Subsamples from a maximum of 10 molded spots per silo were taken and mixed to provide a composite sample for molded spots. All samples were stored at $4^{\circ} \mathrm{C}$ until determination of the $\mathrm{pH}$ and microbial analysis within $24 \mathrm{~h}$. Silage $\mathrm{pH}$ was determined using a Metrohm 532 $\mathrm{pH}$ meter (Metrohm, Herisau, Switzerland) in extracts prepared by adding $180 \mathrm{~g}$ of demineralized water to 20 $\mathrm{g}$ of silage sample and homogenizing for $2 \mathrm{~min}$ in a laboratory blender (Stomacher 400 Circulator; Seward, London, UK) 
A

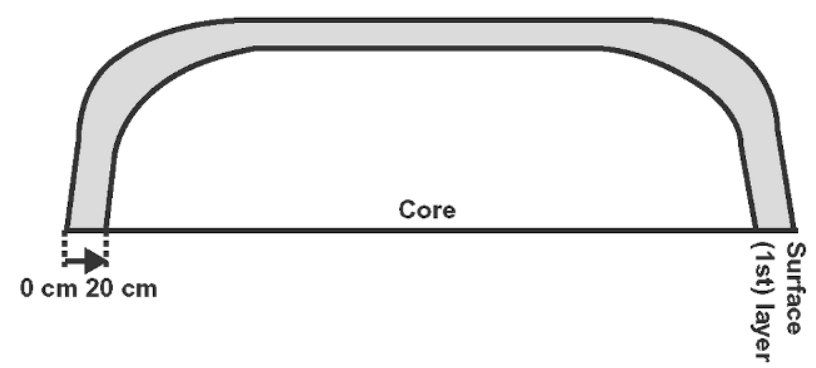

B

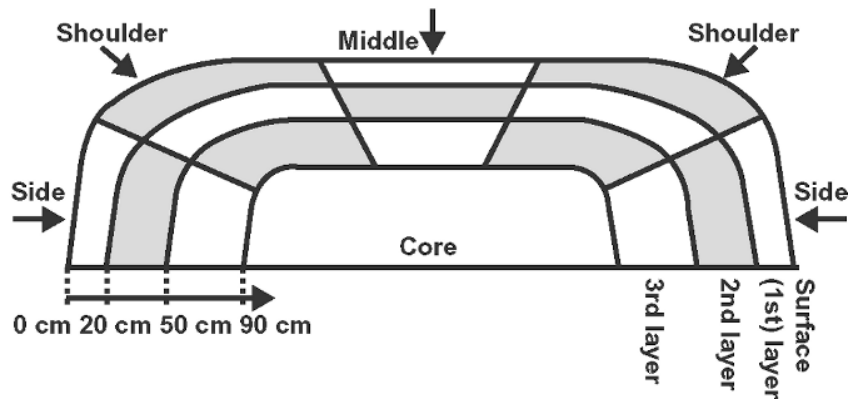

Figure 1. Partitioning of the feed-out face of the silages sampled in survey 1 (A) and survey 2 (B).

\section{Relationships Between Aerobic Deterioration and BAB Spores in Corn Silage (Survey 2)}

The objective of the second survey was to further investigate the relationship between aerobic deterioration and elevated concentrations of BAB spores in corn silage. In this survey, 8 corn silages were sampled on randomly selected farms in the middle and eastern part of the Netherlands. The silages were stored in bunker or clamp silos and were fed to dairy cows. The width of the silages sampled ranged from 7 to $11 \mathrm{~m}$; the height ranged from 1.6 to $2.5 \mathrm{~m}$. On none of the farms had an inoculant been added to the corn silages during ensiling. The feed-out face was divided into 3 layers with widths of $0.2,0.3$, and $0.4 \mathrm{~m}$. The different layers are referred to as the surface, second, and third layer. Each layer was divided into 5 sections of approximately the same length. Including the core, this resulted into 16 sections per silage (see scheme in Figure 1B). In each section, the temperature and penetration resistance (explained below) were measured in duplicate. The temperature was measured at a depth of $0.1 \mathrm{~m}$ using a Pt100 probe (Ebro, Ingolstadt, Germany). In addition, the ambient temperature was measured in ${ }^{\circ} \mathrm{C}$. The area characteristic temperature difference (dT) was defined as the difference between the temperature measured in the silage section and ambient temperature. Sampling for microbiological analyses and $\mathrm{pH}$ measurement was conducted as described for survey 1 .

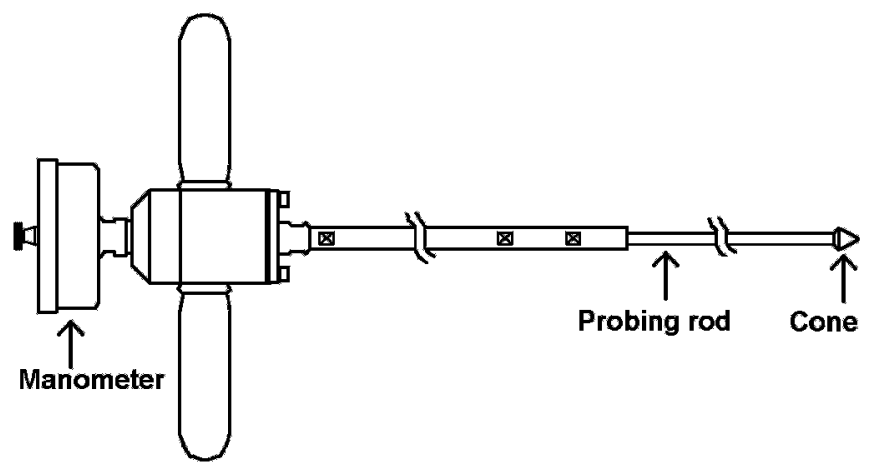

Figure 2. Schematic representation of hand penetrometer (Eijkelkamp Agrisearch Equipment, Giesbeek, the Netherlands).

Penetration resistance was used as an indicator of the density of the silage silo; a higher penetration resistance indicated a higher degree of compaction and a higher density. Penetration resistance was measured using a manual penetrometer (Eijkelkamp Agrisearch Equipment, Giesbeek, the Netherlands), consisting of a manometer, a probing rod $1 \mathrm{~m}$ in length, and a cone of $0.0005 \mathrm{~m}^{2}$ (Figure 2). The device was pushed horizontally into the feed-out face with a constant speed of approximately $2 \mathrm{~cm} / \mathrm{s}$ until the probing rod had penetrated the silage for $0.9 \mathrm{~m}$. The maximum resistance during the measurement was read out from the manometer and corrected for the surface of the cone to obtain a value in $\mathrm{N} / \mathrm{cm}^{2}$.

\section{Microbial Analyses}

Silage extracts were prepared by adding $90 \mathrm{~mL}$ of peptone physiological salt solution (PPS: $1 \mathrm{~g}$ of neutralized bacteriological peptone and $8.5 \mathrm{~g}$ of sodium chloride per liter) to $10 \mathrm{~g}$ of silage sample and homogenizing for 2 min in a laboratory blender (Stomacher; Seward). Microbial counts were determined using a decimal dilution series of silage extracts in PPS. Yeasts and molds (Y\&M) were enumerated on oxytetracycline glucose yeast extract agar (Oxoid, Haarlem, the Netherlands) and after incubation for $4 \mathrm{~d}$ at $25^{\circ} \mathrm{C}$.

The concentration of $\mathrm{BAB}$ spores was determined by the MPN method according to the Dutch Standard (NEN-ISO-6877; NEN, 1994). A volume of $0.1 \mathrm{~mL}$ of diluted extract was added to tubes containing $10 \mathrm{~mL}$ of sterilized milk supplemented with glucose and lactic acid. The tubes were heated for $5 \mathrm{~min}$ at $80^{\circ} \mathrm{C}$ to inactivate vegetative cells and to trigger the germination of spores. The tubes were sealed with paraffin and incubated for $4 \mathrm{~d}$ at $37^{\circ} \mathrm{C}$. A tube scored positive if gas formation was visible after incubation. 
Table 1. Concentration of butyric acid bacteria (BAB) spores, concentration of yeasts and molds, and $\mathrm{pH}$ of samples from core, surface layer, and molded spots of grass and corn silages and from the mixed silages in the barn (survey 1)

\begin{tabular}{|c|c|c|c|c|c|c|c|c|c|}
\hline \multirow[b]{2}{*}{ Sample from } & \multicolumn{3}{|c|}{$\begin{array}{l}\text { Concentration of BAB } \\
\text { spores, } \log _{10} / \mathrm{g}\end{array}$} & \multicolumn{3}{|c|}{$\begin{array}{l}\text { Concentration of yeasts } \\
\text { and molds, } \log _{10} \mathrm{cfu} / \mathrm{g}\end{array}$} & \multicolumn{3}{|c|}{$\mathrm{pH}^{2}$} \\
\hline & Mean $^{1}$ & SEM & Range & Mean & SEM & Range & Mean & SEM & Range \\
\hline Grass-core, $\mathrm{n}=21$ & $3.0^{\mathrm{a}}$ & 0.2 & $<1.5-4.6$ & $3.2^{\mathrm{a}}$ & 0.2 & $<2.0-4.9$ & $4.7^{\mathrm{a}}$ & 0.1 & \\
\hline surface layer, $\mathrm{n}=21$ & $3.1^{\mathrm{a}}$ & 0.2 & $1.6-5.4$ & $5.1^{\mathrm{d}}$ & 0.4 & $2.3-8.3$ & $5.3^{\mathrm{d}}$ & 0.2 & 3.6 \\
\hline -molded spots, $\mathrm{n}$ & $3.9^{\mathrm{bc}}$ & 0.3 & $2.0-5.4$ & $6.8^{\mathrm{d}}$ & 0.3 & $4.5-8.5$ & $7.1^{\mathrm{e}}$ & 0.3 & \\
\hline Corn-core, $\mathrm{n}=21$ & $3.0^{\mathrm{a}}$ & 0.3 & $<1.5-5.4$ & $5.8^{\mathrm{bc}}$ & 0.4 & $2.2-8.3$ & $3.9^{b}$ & 0.1 & $3.5-4$ \\
\hline Corn-surface layer, $\mathrm{n}=21$ & $3.6^{\mathrm{ab}}$ & 0.3 & $1.6-6.2$ & $6.9^{\mathrm{d}}$ & 0.3 & $2.5-8.0$ & $4.2^{\mathrm{c}}$ & 0.1 & $3.5-5$ \\
\hline Corn-molded spots, $\mathrm{n}=16$ & $5.5^{\mathrm{d}}$ & 0.3 & $2.8-7.2$ & $7.8^{\mathrm{e}}$ & 0.2 & $5.2-8.5$ & $6.6^{\mathrm{e}}$ & 0.3 & $4.5-8$ \\
\hline Mixed silages in barn, $\mathrm{n}=21$ & $4.2^{\mathrm{bc}}$ & 0.2 & $2.9-5.4$ & $6.4^{\text {cd }}$ & 0.2 & $3.7-7.7$ & $4.7^{\mathrm{a}}$ & 0.1 & $4.0-6.3$ \\
\hline
\end{tabular}

${ }^{\mathrm{a}-\mathrm{e}}$ Within columns, values with different superscripts are different $(P<0.05$; the lowest value is marked with an a).

${ }^{1}$ The concentration of BAB spores was determined using the most-probable-number technique for enumeration.

${ }^{2} \mathrm{~A} t$-test was applied for groups with unequal variance.

\section{Statistical Analyses}

All microbial counts were $\log _{10}$ transformed to obtain log-normal distributed data. To calculate averages, the values below the detection level (detection levels: 30 $\mathrm{BAB}$ spores/g and $100 \mathrm{Y \& M} / \mathrm{g}$ ) were assigned a value corresponding to half of the detection level (i.e., $15 \mathrm{BAB}$ spores/g and $50 \mathrm{Y} \& \mathrm{M} / \mathrm{g}$ ). Student's $t$-test was used to detect significant differences among samples (Snedecor and Cochran, 1989).

\section{RESULTS}

\section{BAB Spores in Grass and Corn Silage (Survey 1)}

Table 1 lists the concentrations of BAB spores, the concentrations of $\mathrm{Y} \& \mathrm{M}$, and the $\mathrm{pH}$ measured in the samples obtained in the first survey. The average concentration of BAB spores in the samples from the core of both the grass and corn silages was $3.0 \log _{10} / \mathrm{g}$. The concentrations in the core of grass and corn silages were, respectively, in 52 and $62 \%$ of the silages below $3 \log _{10} / \mathrm{g}$, the initial contamination level of silage (Pahlow et al., 2003). Based on a mathematical model of the contamination of milk with BAB spores, Vissers et al. (2006) determined that concentrations of BAB above 5 $\log _{10} / \mathrm{g}$ in silages fed gives a probability of more than $5 \%$ that the concentration in FTM will exceed 1,000 $\mathrm{BAB} / \mathrm{L}$. Based on this criterion, all silage cores, except for one corn silage, were considered to be of sufficient quality. The average concentrations of $\mathrm{BAB}$ spores in the surface layers of grass and corn silage were not significantly different $(P>0.10)$. However, concentrations above $5 \log _{10} / \mathrm{g}$ were detected more frequently in the surface layers of corn silage (19\%) than in the core of corn silages (5\%), the surface layer of grass silages $(5 \%)$, and the core of grass silages $(0 \%$; Figure 3$)$.

In both grass silage and corn silage, the concentrations of $\mathrm{BAB}$ spores were higher in areas with visible

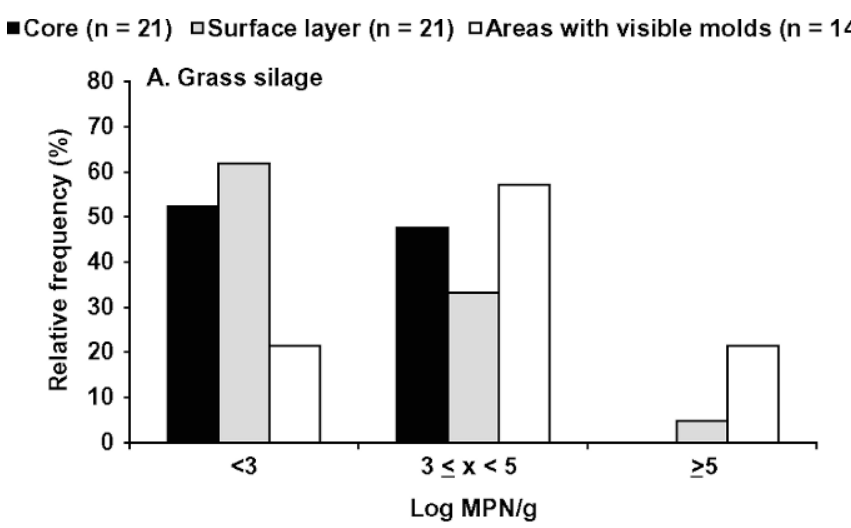

-Core $(n=21)$ aSurface layer $(n=21)$ aAreas with visible molds $(n=16)$

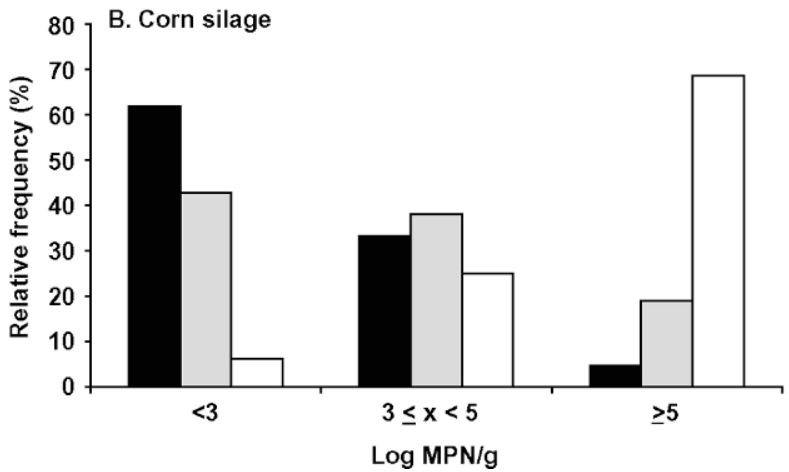

Figure 3. Distribution of the concentration of butyric acid bacteria $(\mathrm{BAB})$ spores as measured in grass $(\mathrm{A})$ and corn $(\mathrm{B})$ silage in survey 1. $\mathrm{MPN}=$ Most probable number. 
molds than in the surface layer and core. The highest concentrations were present in molded-spot samples from corn silages (average of $5.5 \log _{10} \mathrm{MPN} / \mathrm{g}$ ). In approximately $70 \%$ of the cases, these samples contained more than $5 \log _{10} \mathrm{MPN} / \mathrm{g}$. The average concentration of $\mathrm{BAB}$ spores in molded spots present in grass silage was $4 \log _{10} \mathrm{MPN} / \mathrm{g}$, which was significantly lower than the concentration in molded spots present in corn silage $(P<0.001)$. In both silage types, visible molds were most often present in the shoulders of the silage or as blue-colored lumps at depths up to $\sim 1 \mathrm{~m}$ from the surface. In general, the areas with visible molds were roughly 5 to 10 times larger in corn silages than in grass silages. Most farmers did not remove these areas from the silage ration offered to the cows.

The BAB spore concentration in the mixed silages in the barn was less than $3 \log _{10} \mathrm{MPN} / \mathrm{g}$ at $29 \%$ of the farms and above the critical value of $5 \log _{10} \mathrm{MPN} / \mathrm{g}$ at $10 \%$ of the farms. Remarkably, the average concentration in the mixed silage in the barn was significantly higher than the average concentrations measured in the grass core (difference $=1.2 \log _{10} \mathrm{MPN} / \mathrm{g}, P<0.001$ ), grass surface layer $\left(\right.$ difference $=1.1 \log _{10} \mathrm{MPN} / \mathrm{g}, P<$ 0.001 ), and corn core (difference $=1.2 \log _{10} \mathrm{MPN} / \mathrm{g}, P$ $<0.001$; Table 1). Also, the average concentration in the corn surface layer seemed to be lower (difference = $0.6 \log _{10} \mathrm{MPN} / \mathrm{g}, P=0.09$ ). This is a remarkable result because the mixed silage in the barn was, for more than $90 \%$, composed of cores and surface layers of the grass and corn silages fed.

Samples with the highest concentration of $\mathrm{BAB}$ spores also contained the highest number of Y\&M. In both silage types, the highest concentrations of $Y \& M$ were measured in molded spots and the lowest were measured in the core. Concentrations of Y\&M in samples from grass silages were lower than in samples from corn silages. Concentrations above $5 \log _{10} \mathrm{cfu} / \mathrm{g}$ predispose a silage to aerobic stability problems (Honig, 1991). None of the core samples and $57 \%$ of the surface layer samples of grass silage contained more than 5 $\log _{10} \mathrm{cfu} / \mathrm{g}$ of $\mathrm{Y} \& \mathrm{M}$. In corn silage, concentrations above $5 \log _{10} \mathrm{cfu} / \mathrm{g}$ of $\mathrm{Y} \& \mathrm{M}$ were detected more often: in $76 \%$ of the core samples and in $90 \%$ of the surface layer samples.

In both silages, the highest $\mathrm{pH}$ values were detected in the molded spots and the lowest values were detected in the core. The $\mathrm{pH}$ values were higher in the grass silage than in the corn silage. Among other factors, the $\mathrm{pH}$ of silage after the fermentation period depends on the DM content. In general, silage $\mathrm{pH}$ increases with increasing DM (Weissbach, 1996). The average DM content of the grass silage sampled in survey 1 was $460 \mathrm{~g} /$ $\mathrm{kg}$ (minimum of $250 \mathrm{~g} / \mathrm{kg}$, maximum of $600 \mathrm{~g} / \mathrm{kg}$ ). The range of $\mathrm{pH}$ values measured in the core of the grass silage (4.0 to 5.6) was typical for grass silages with this range of DM contents (Spoelstra, 1990). However, no significant correlations $(P>0.2)$ were observed between $\mathrm{DM}$ and $\mathrm{pH}$ or microbial concentrations measured in core samples from the grass silages. The average DM of the corn silages was $330 \mathrm{~g} / \mathrm{kg}$ and varied less than the DM content of the grass silages (minimum of 300 $\mathrm{g} / \mathrm{kg}$, maximum of $340 \mathrm{~g} / \mathrm{kg}$ ).

\section{Relationships Between Aerobic Deterioration and BAB Spores in Corn Silage (Survey 2)}

Table 2 shows the concentration of BAB spores, concentration of $\mathrm{Y} \& \mathrm{M}$, penetration resistance, dT between silage and ambient temperature, and $\mathrm{pH}$ measured in the 16 sections of the 8 corn silages sampled in the second survey. Significant differences were observed among the different layers (surface, second, and third; Figure 1) but not between the different segments (side, shoulder, and middle); therefore, the results are summarized per layer.

In total, 16 (out of 128) samples contained more than $5 \log _{10} \mathrm{BAB}$ spores/g. These contamination levels were most often $(63 \%)$ found in the surface layer and never in the third layer. In samples from the core, BAB spore concentrations were always less than $3 \log _{10} / \mathrm{g}$, implying that after ensiling no growth of $\mathrm{BAB}$ had occurred within the cores. All corn silages included in this survey had at least one section with more than $5 \log _{10} / g$, indicating that in all silages, growth of $\mathrm{BAB}$ had occurred in at least one section.

Penetration resistance was measured as an indicator of density. The penetration resistance increased by approximately $25 \mathrm{~N} / \mathrm{cm}^{2}$ per layer, going from the surface layer (average $25 \mathrm{~N} / \mathrm{cm}^{2}$ ) to the core (average $96 \mathrm{~N} / \mathrm{cm}^{2}$ ). The differences observed between the different layers were significant $(P<0.001)$. Within layers, no significant differences were observed, although the resistance in the shoulders (sections 4 and 10) of the outer layer tended to be lower than the resistance in the sides (sections 1 and 13, $P=0.07$ ) and middle (section $10, P=$ 0.08 ). The results indicate that the lowest penetration resistances were measured in the layers in which the highest concentrations of BAB spores occurred.

Similar to the concentration of BAB spores, the concentration of $\mathrm{Y} \& \mathrm{M}$, the $\mathrm{dT}$, and the $\mathrm{pH}$ values were highest in the surface layer and lowest in the core. For $\mathrm{dT}$ and $\mathrm{pH}$, the range of values measured was largest in the surface layer and lowest in the core. However, for Y\&M the largest range of concentrations was measured in the core and the smallest range was in the surface layers. All sections in the surfaces layers of the 8 corn silages contained more than $5 \log _{10} \mathrm{Y} \& \mathrm{M} / \mathrm{g}$. 
The results demonstrate that high concentrations of $\mathrm{BAB}$ spores and indicators of aerobic deterioration (high Y\&M counts, increased $\mathrm{dT}$ and $\mathrm{pH}$ ) occurred in the same layer. To confirm the relationship between high $\mathrm{BAB}$ spore concentrations and aerobic deterioration, the results of survey 2 were analyzed using 3 criteria for aerobic deterioration:

1. concentrations of $\mathrm{Y} \& \mathrm{M}$ higher than $5 \log _{10} \mathrm{cfu} / \mathrm{g}$;

2. dT larger than $5^{\circ} \mathrm{C}$; and

3. $\mathrm{pH}$ of the section higher than 4.4 (minimal $\mathrm{pH}$ required for growth of Clostridium tyrobutyricum (Thylin et al., 1995).

First, the number of sections that met each criterion or none of the criteria was counted. Second, for the sections meeting a criterion, the distribution of the concentration of $\mathrm{BAB}$ spores was determined. The results are presented in Figure 4.

The percentage of sections that met criteria 1,2 , and 3 were, respectively, 88,38 , and $13 \%$. All but one of the sections with a dT larger than $5^{\circ} \mathrm{C}$ contained more than $5 \log _{10} \mathrm{Y} \& \mathrm{M} / \mathrm{g}$. All sections with a $\mathrm{pH}$ higher than 4.4 contained more than $5 \log _{10} \mathrm{Y} \& \mathrm{M} / \mathrm{g}$ and showed a dT of more than $5^{\circ} \mathrm{C}$. These observations correspond to a process of aerobic deterioration that started with the growth of Y\&M, followed by an increase in the temperature caused by microbial activity, and finally resulted in an increase in the $\mathrm{pH}$.

The relative frequency of concentrations of more than $5 \log _{10} \mathrm{BAB}$ spores/g increased with increasing signs of aerobic deterioration. The distribution of the concentration of $\mathrm{BAB}$ spores in the sections with a concentration of Y\&M above $5 \log _{10} \mathrm{cfu} / \mathrm{g}$ was similar to the distribution observed in all sections sampled; approximately $13 \%$ of the samples contained more than $5 \log _{10} \mathrm{BAB} /$ $\mathrm{g}$ and $19 \%$ more than $3 \log _{10} \mathrm{BAB} / \mathrm{g}$. The relative frequency of a concentration of BAB spores above $5 \log _{10}$ $\mathrm{MPN} / \mathrm{g}$ increased to $21 \%$ when dT was more than $5^{\circ} \mathrm{C}$ and to $50 \%$ when the $\mathrm{pH}$ of the section was above 4.4. Concentrations below $3 \log _{10} \mathrm{BAB}$ spores/g were never observed in sections with an increased $\mathrm{pH}$, whereas sections that met none of the criteria always contained less than $5 \log _{10}$ BAB spores/g.

\section{DISCUSSION}

Traditionally, grass silages have generally been considered a more important source of $\mathrm{BAB}$ spores than corn silages, because in grass silages much higher $\mathrm{BAB}$ spore concentrations have been measured than in corn silages (Stadhouders and Spoelstra, 1990). The results of this study indicate that at present on dairy farms in the Netherlands, BAB spore concentrations in grass 

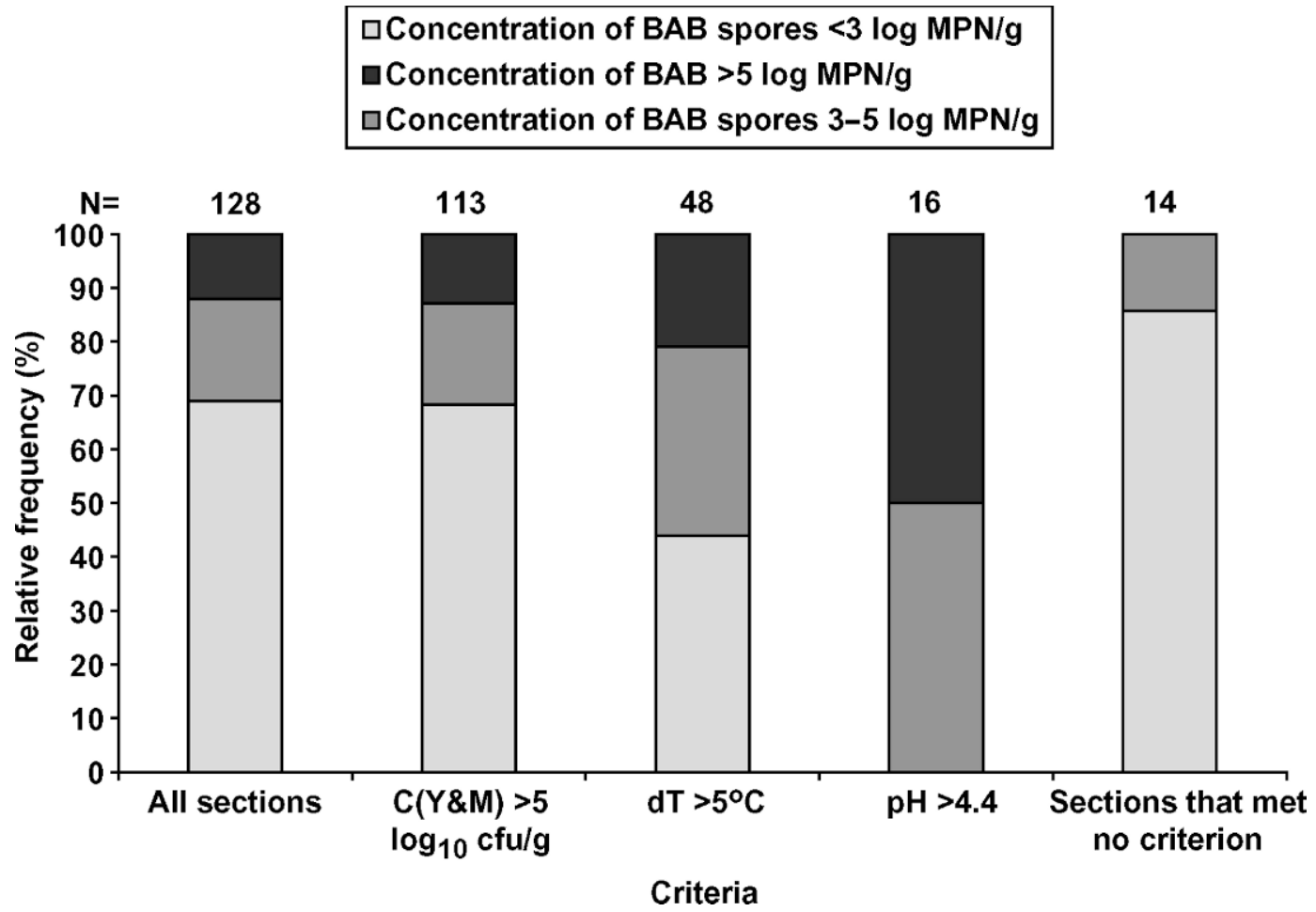

Figure 4. Distribution of the concentration of butyric acid bacteria (BAB) spores measured in the sections meeting the criteria defined on the $x$-axis (results of survey 2 ). $\mathrm{C}(\mathrm{Y} \& \mathrm{M})=$ Concentration of yeasts and molds; MPN = most probable number; $\mathrm{dT}=$ temperature difference between the silage section and ambient temperature.

and corn silages are comparable. Consequently, corn silage contributes significantly to the concentration of $\mathrm{BAB}$ spores in the ration and in FTM. Based on the distribution of $\mathrm{BAB}$ spores in grass and corn silages (Figure 3), the contribution of corn silage appears larger than that of grass silage on the farms sampled.

\section{Aerobic Deterioration of Corn Silage and Growth of $B A B$}

A generally accepted view is that high $\mathrm{BAB}$ spore concentrations in silage are associated with anaerobic instability of silage because of an insufficient $\mathrm{pH}$ decline during the primary fermentation phase (Pahlow et al., 2003). The results of the present study, however, show that increased $\mathrm{BAB}$ spore concentrations in both grass and corn silages were related to aerobic instability problems rather than to anaerobic instability problems. High $\mathrm{BAB}$ spore concentrations were detected particularly in corn silage samples showing signs of aerobic deterioration, such as high Y\&M concentrations, high $\mathrm{dT}$, and elevated $\mathrm{pH}$ (Tables 1 and 2). These samples were almost exclusively located in surface layers (top $50 \mathrm{~cm}$ ) and in sections with a low density (i.e., in parts that were easily infiltrated by oxygen). Obvious signs of aerobic deterioration (e.g., visibility of molds, increased $\mathrm{pH}$ ) were always accompanied by increased (above 3 $\left.\log _{10} \mathrm{MPN} / \mathrm{g}\right)$ or high concentrations of BAB spores (above $5 \log _{10}$ MPN/g; Figures 3 and 4).

The growth of strictly anaerobic BAB in aerobically deteriorated parts of silage may seem contradictory. However, microbial ecosystems with aerobic and anaerobic zones are found in many environments (e.g., in sediments, biofilms, and intestines; Brune et al., 1995; Stoodley et al., 2002; Fourcans et al., 2004). The underlying mechanism of growth of $\mathrm{BAB}$ in air-exposed parts of silage is presumably related to the succession of steps occurring in the process of aerobic deterioration (Pahlow et al., 2003). Oxygen penetrating the silage initiates the growth of aerobic, acid-tolerant yeasts and acetic acid bacteria. These bacteria oxidize residual sugars and organic acids, leading to an increase in $\mathrm{pH}$. Because the initial concentration of aerobic microorganisms is low, oxygen initially penetrates relatively deep into the silage. But as the concentration of the aerobic microorganisms increases, the consumption of oxygen increases. As a result, oxygen penetrates less deeply into the silage, and deeper parts of the silage return to anaerobic conditions (Muck and Pitt, 1994). Consequently, just below the surface, anaerobic niches with an in- 
creased $\mathrm{pH}$ may develop. We hypothesize that the high concentrations of BAB spores detected in the top $50 \mathrm{~cm}$ of the corn silage and in molded spots were due to the frequent occurrence of anaerobic niches as a result of the mechanism described above. The growth of $\mathrm{BAB}$ associated with aerobic deterioration has been found previously in grass silage (Jonsson, 1991).

Oxygen can penetrate the surface layers of corn silage during the storage period and after the silo is opened (Parsons, 1991; McGechan and Williams, 1994). Additional research should be undertaken to establish whether high concentrations of BAB spores already occur during the storage period or whether the growth of $\mathrm{BAB}$ is initiated only after the silage is opened. The process by which oxygen penetrates into the silage and ultimately leads to the growth of BAB requires sufficient amounts of oxygen penetration into the silo and requires time. The growth rate of $\mathrm{BAB}$ is relatively low, $0.12 / \mathrm{h}$ at the optimal temperature of $37^{\circ} \mathrm{C}$ and $\mathrm{pH}$ of 5.6 (Thylin et al., 1995). The growth of BAB in silage after oxygen penetration is limited by this slow growth rate, especially because growth conditions are not optimal. During the storage period, the amount of oxygen that penetrates the silage per unit of time will be relatively low, but the time the silage is available to undergo the entire process described above is several months. After the silage is opened, presumably larger amounts of oxygen can penetrate it, speeding up the process of aerobic deterioration, but the time available for the formation of anaerobic niches with an increased $\mathrm{pH}$ and growth of $\mathrm{BAB}$ is less because the silage face is removed regularly (in the Netherlands a feed-out speed of $1.5 \mathrm{~m}$ per week is advised).

In the current study, silage samples have not been analyzed for organic acids. Therefore, it is unknown whether the corn silage samples with high BAB spore concentrations contained significant amounts of butyric acid, as is usually the case, for instance, in grass silage with a high $\mathrm{BAB}$ spore concentration caused by anaerobic instability. This subject needs further investigation in future studies.

\section{Impact on BAB Spores in the Ration}

The results of this study demonstrate that the concentration of $\mathrm{BAB}$ spores within the same corn silage varies strongly (from $<1.5 \log _{10} / g$ to $>7.0 \log _{10} / g$ ). Extremely high concentrations ( $>5 \log _{10} \mathrm{MPN} / \mathrm{g}$ ) were found only in parts that constituted a relatively small fraction of the total mass (1 to 10\%). However, these small fractions are the main source of $\mathrm{BAB}$ spores in the ration. If, for example, $10 \%$ of the silage fed contains $5 \log _{10}$ $\mathrm{MPN} / \mathrm{g}$, the silages fed to cows will contain at least 4 $\log _{10}$ MPN/g. This explains why, in the first survey, the average concentration found in the mixed silage in the barn was significantly higher than the average concentrations measured in the core and surface layers of grass and corn silage, which represent the bulk of the material fed (Table 1).

One could argue that the elevated concentration of $\mathrm{BAB}$ spores in mixed silage in the barn may be due to growth of $\mathrm{BAB}$ in the period during which the feed is in the barn (generally less than $1 \mathrm{~d}$ ). However, calculations using the theoretical growth rate of C. tyrobutyricum (Vissers et al., 2006), the most important BAB, as well as additional experiments investigating the change in the concentration of BAB spores in the feeds in the barn (results not shown) indicate that growth of $\mathrm{BAB}$ does not occur at this stage.

\section{Control Measures}

To control the concentration of BAB spores in the mixed silages in the barn, it is most important to prevent local growth of $\mathrm{BAB}$ in grass and corn silage. Growth can probably be prevented by limiting the penetration of oxygen or inhibiting the detrimental effect of oxygen penetration, for instance by addition of an inhibitor of aerobic deterioration by $\mathrm{Y} \& \mathrm{M}$, such as propionic, sorbic, and benzoic acids and Lactobacillus buchneri (Driehuis et al., 1999; Kung et al., 2003). Achieving a high density of silage is the most important way to limit the penetration of oxygen. Muck and Holmes (2000) performed an extensive study to identify factors that affect the density of corn and alfalfa silages. They found that using heavier packaging tractors, lower initial layer thicknesses, and longer packing times affected silage density. A lower initial layer thickness means that each delivered load of freshly harvested corn is spread over a large area, allowing for a higher compaction of the freshly added corn before a new load is delivered. In recent years the capacity of corn harvesting machines has increased, increasing the mass of harvest silage delivered to the silo per unit of time. However, ensiling practices have not been adjusted accordingly, resulting in decreased packing times per delivery of harvested corn. This could explain why high concentrations of BAB spores have only recently been detected in corn silages. After the silage is opened, a high feed removal rate may be important because it limits the time available for aerobic deterioration, formation of anaerobic niches with an increased $\mathrm{pH}$, and growth of BAB. However, in practice, complete prevention of oxygen penetration and growth of Y\&M will be impossible. The highest concentration of BAB spores was found in visibly molded and deteriorated parts of the silage. During feed-out, removal of these areas is probably an 
effective measure to reduce the overall concentration in the mixed silages offered to the cows.

\section{CONCLUSIONS}

On farms in the Netherlands, corn silage was a more important source of BAB spores in FTM than was grass silage. The concentration of BAB spores consumed by cows was determined mainly by a small fraction of silage with a high concentration. High concentrations, above $5 \log _{10} / g$, in corn silage were associated with signs of aerobic deterioration, namely, a concentration of Y\&M above $5 \log _{10} / \mathrm{g}$, a dT between silage and ambient temperature of more than $5^{\circ} \mathrm{C}$, a pH higher than 4.4 , and visible molds. The higher the extent of aerobic deterioration, the higher the concentration of $\mathrm{BAB}$ spores.

\section{REFERENCES}

Bergere, J. L., P. Gouet, J. Hermier, and G. Mocquot. 1968. Les Clostridium du groupe butyrique dans les produit laitiers. Ann. Inst. Pasteur (Paris) 19:41-54.

Brune, A., E. Miambi, and J. A. Breznak. 1995. Role of oxygen and the intestinal microflora in the metabolism of lignin-derived phenylpropanids and other monoaromatic compounds by termites. Appl. Environ. Microbiol. 61:2688-2695.

Delves-Broughton, J., P. Blackburn, R. J. Evans, and J. Hugenholtz. 1996. Applications of the bacteriocin, nisin. Antonie Van Leeuwenhoek 69:193-202.

Driehuis, F., S. J. W. H. Oude Elferink, and S. F. Spoelstra. 1999. Anaerobic lactic acid degradation during ensilage of whole crop maize inoculated with Lactobacillus buchneri inhibits yeast growth and improves aerobic stability. J. Appl. Microbiol. 89:583-594.

Driehuis, F., and M. C. Te Giffel. 2005. Butyric acid bacteria spores in whole crop maize silage. Page 271 in Silage Production and Utilisation, Proc. 14th Int. Silage Conf., Belfast, UK. R. S. Park and M. D. Stronge, ed. Wageningen Academic Publishers, Wageningen, the Netherlands.

Fourcans, A., T. Garcia de Oteyza, A. Wieland, A. Solé, E. Diestra, J. Van Bleijswijk, J. O. Grimalt, M. Kühl, I. Esteve, G. Muyzer, P. Caumette, and R. Duran. 2004. Characterization of funtional bacterial groups in a hypersaline microbial mat community. FEMS Microbiol. Ecol. 51:55-70.

Honig, H. 1991. Reducing losses during storage and unloading of silage. Silage Conservation Towards 2000, Braunschweig, Germany. G. Pahlow and H. Honig, ed. Institute of Grassland and Forage Research and Federal Research Center of Agriculture Braunschweig-Völkenrode, Braunschweig, Germany.

Jonsson, A. 1991. Growth of Clostridium tyrobutyricum during fermentation and aerobic deterioration of grass silage. J. Sci. Food Agric. 54:557-568.
Klijn, N., F. F. J. Nieuwenhof, J. D. Hoolwerf, C. B. v. d. Waals, and A. H. Weerkamp. 1995. Identification of Clostridium tyrobutyricum as the causative agent of late blowing in cheese by speciesspecific PCR amplification. Appl. Environ. Microbiol. 61:29192924.

Kung, L., M. R. Stokes, and C. J. Lin. 2003. Silage additives. Pages 305-360 in Silage Science and Technology. L. Al-Amoodi, ed. American Society of Agronomy, Crop Science Society of America, and Soil Science Society of America, Madison, WI.

McGechan, M. B., and A. G. Williams. 1994. A model of air infiltration losses during silage storage. J. Agric. Eng. Res. 57:237-249.

Muck, R. E. and B. J. Holmes. 2000. Factors affecting bunker silo densities. App. Eng. Agric. 16:613-619.

Muck, R. E., and R. E. Pitt. 1994. Aerobic deterioration in corn silage relative to the silo face. Trans. ASAE 37:735-743.

NEN (Netherlands Normalisation Institute). 1994. NEN-ISO-6877: Milk and milk products-Detection of spores of butyric acid bacteria and determination of the content of spores of butyric acid bacteria. Pages 1-4 in NEN 6877. Vol. 6877. Netherlands Normalisation Institute, Delft, the Netherlands.

Pahlow, G., R. E. Muck, F. Driehuis, S. J. W. H. Oude Elferink, and S. F. Spoelstra. 2003. Microbiology of ensiling. Pages 31-93 in Silage Science and Technology. L. Al-Amoodi, ed. American Society of Agronomy, Crop Science Society of America, and Soil Science Society of America, Madison, WI.

Parsons, D. J. 1991. Modelling gas flow in a silage clamp after opening. J. Agric. Eng. Res. 50:209-218.

Snedecor, G. W., and W. G. Cochran. 1989. Statistical Methods. Iowa State University Press, Ames, IA.

Spoelstra, S. F. 1990. Comparison of the content of clostridial spores in wilted grass silage ensiled in either laboratory, pilot-scale or farm silos. Neth. J. Agric. Sci. 38:423-434.

Stadhouders, J. 1990. Prevention of butyric acid fermentation by the use of nitrate. Bull. Int. Dairy Fed. 251:40-46.

Stadhouders, J., and S. F. Spoelstra. 1990. Prevention of the contamination of raw milk by making a good silage. Bull. Int. Dairy Fed. 251:24-31.

Stoodley, P., K. Sauer, D. G. Davies, and J. W. Costerton. 2002. Biofilms as complex differentiated communities. Annu. Rev. Microbiol. 56:187-209.

Thylin, I., P. Schuisky, S. Lindgren, and J. C. Gottschal. 1995. Influence of $\mathrm{pH}$ and lactic acid concentration on Clostridium tyrobutyricum during continuous growth in a $\mathrm{pH}$-autostat. J. Appl. Bacteriol. 79:663-670.

Vissers, M. M. M., F. Driehuis, M. C. Te Giffel, P. De Jong, and J. M. G. Lankveld. 2006. Improving farm management by modeling the contamination of farm tank milk with butyric acid bacteria. J. Dairy Sci. 89:850-858.

Waes, G., A. v. Heddeghem, and A. Van Heddeghem. 1990. Prevention of butyric acid fermentation by bacterial centrifugation of the cheese milk. Bull. Int. Dairy Fed. 251:47-50.

Weissbach, F. 1996. New developments in crop conservation. Pages 11-25 in Proc. XIth Int. Silage Conf., Aberystwyth. D. I. H. Jones, R. Jones, R. Dewhurst, R. Merry, and P. M. Hagh, ed. IGER, Aberystwyth, UK. 